ИССЛЕДОВАНИЕ

СТАБИЛЬНОСТИ УГЛОВ

ОРИЕНТАЦИИ ИЗМЕРИТЕЛЬНЫХ ОСЕЙ АКСЕЛЕРОМЕТРОВ

\section{В ИНЕРЦИАЛЬНОМ}

\section{ИЗМЕРИТЕЛЬНОМ БЛОКЕ}

\author{
Ю. Ю.Колбас, tigra-e@rambler.ru, \\ А.Г.3убов,zzyba@yandex.ru, \\ Л.В.Еремин, leremin@outlook.com \\ АО "НИИ "Полюс" им. М.Ф. Стельмаха" Москва, \\ www.polyus.info
}

Рассмотрены зависимости матрицы ориентации измерительных осей акселерометров в инерциальном измерительном блоке (ИИБ) от температуры и механических ударных и вибрационных воздействий. Показано, что при отдельном расположении гироскопов и акселерометров не возникает дополнительных ошибок ориентации их измерительных осей после вибрации и ударов.

\section{ВВЕДЕНИЕ}

Ошибки матрицы ориентации Са измерительных осей акселерометров, установленных в инерциальный измерительный блок (ИИБ), во многом определяют точность инерциальной навигации подвижных объектов [1,2]. Поскольку сделать положения измерительных осей акселерометров абсолютно ортогональными весьма затрудни тельно, то на этапе заводской калибровки определяют матрицу направляющих косинусов измерительных осей акселерометров Са относительно некоторой ортогональной системы координат, обычно связанной с посадочными поверхностями ИИБ. Для определения проекций ускорений на осях этой ортогональной системы координат Аииь необходимо умножить вектор $\mathrm{A}_{\mathrm{a}}$ показаний акселерометров на обратную матрицу $\overline{\mathrm{C}} \mathrm{a}=\overline{\mathrm{C}} \mathrm{a}^{-1}$.

Ошибки матрицы ориентации состоят из нескольких составляющих:

- $\Delta \mathrm{Ca}_{\mathrm{K}}$ - погрешности заводской калибровки, связанные как с используемым оборудованием, так и с методикой;

\section{STUDY OF THE ORIENTATION} ANGLES STABILITY OF THE MEASURING AXES OF ACCELEROMETERS IN AN INERTIAL MEASURING UNIT

\author{
Y.Y.Kolbas, tigra-e@rambler.ru, \\ A.G.Zubov,zzyba@yandex.ru, \\ L.V.Eremin,leremin@outlook.com \\ JSC "M. F. Stelmakh Research Institute "Polyus" Moscow, \\ www.polyus.info
}

The dependences of the orientation matrix of the measuring axes of accelerometers in the inertial measuring unit (IMU) on temperature and mechanical impact and vibration effects are discussed. It is shown that with separate arrangement of gyroscopes and accelerometers, there are no additional errors in orientation of their measuring axes after vibration and impacts.

\section{INTRODUCTION}

Errors of the orientation matrix $\mathrm{Ca}$ of the measuring axes of the accelerometers installed in the inertial measuring unit (IMU) largely determine the accuracy of the inertial navigation of mobile objects [1, 2]. Since it is very difficult to make the position of the measuring axes of accelerometers absolutely orthogonal, the matrix of the direction cosines of the measuring axes of accelerometers $\mathrm{Ca}$ is determined at the stage of factory calibration with respect to some orthogonal coordinate system usually associated with the mounting surfaces of the IMU. To determine the projections of the accelerations on the axes of this orthogonal coordinate system $A_{I M U}$, it is necessary to multiply the vector of the accelerometer readings $A_{a}$ by the inverse matrix $\overline{\mathrm{C}} \mathrm{a}=\overline{\mathrm{C}} \mathrm{a}^{-1}$.

Errors of the orientation matrix consist of several components:

- $\quad \Delta \mathrm{Ca}_{\mathrm{K}}$ - factory calibration errors related to both the equipment used and the methodology;

- $\Delta \mathrm{Ca}_{\mathrm{T}}$ - temperature drifts of directions of measuring axes of accelerometers;

- $\Delta \mathrm{Ca}_{\mathrm{M}}$ - changes in the directions of the measuring axes of accelerometers after mechanical impact and vibration effects. 
- $\quad \Delta \mathrm{Ca}_{\mathrm{T}}$ - температурные уходы направлений измерительных осей акселерометров;

- $\Delta \mathrm{Ca}_{\mathrm{M}}$ - изменения направлений измерительных осей акселерометров после механических ударных и вибрационных воздействий.

Поскольку все составляющие ошибок независимы, суммарная погрешность элементов матрицы ориентации акселерометров легко может быть рассчитана по формуле.

Рассмотрим каждую из составляющих отдельно.

\section{МЕТОДИКА ОПРЕДЕЛЕНИЯ МАТРИЦЫ ОРИЕНТАЦИИ ИЗМЕРИТЕЛЬНЫХ ОСЕЙ АКСЕЛЕРОМЕТРОВ, ИНСТРУМЕНТАЛЬНЫЕ И МЕТОДИЧЕСКИЕ ПОГРЕШНОСТИ}

Определение матрицы ориентации Са измерительных осей акселерометров в ортогональной системе координат X, Y, Z, связанной с посадочными поверхностями ИИБ, осуществляется по данным измерений выходных сигналов с акселерометров на высокоточном двухосном стенде, оснащенном камерой тепла и холода (KTX). Нормаль к установочной платформе стенда совпадает с осью 1 стенда. Ось 2 стенда ортогональна оси 1 и расположена горизонтально. Стенд установлен таким образом, что при нулевых углах, заданных для обеих осей стенда, ось 1 направлена вверх, а ось 2 - в горизонтальной плоскости. ИИБ при помощи прецизионной оснастки размещается и жестко фиксируется на установочной платформе стенда таким образом, что ось Ү ИИБ совпадает с осью 1 стенда, а ось X-с осью 2 (рис. 1, положение $\mathrm{Y}_{\mathrm{a}}$ ). При помощи поворотов на $90^{\circ}$ и $180^{\circ}$ относительно осей 1 и 2 двухосный стенд позволяет реализовать 12 положений ИИБ, изображенных на рис.1. При этом вследствие погрешностей установки стенда вектор кажущегося ускорения $\overrightarrow{\mathrm{G}}$, обусловленного силой тяжести, проецируется на оси ортогональной системы координат ИИБ, как показано на рис. 1 под каждым из положений ИИБ, где [·]Т - операция транспонирования вектора $[\cdot]$, причем, $\overrightarrow{\mathrm{G}}_{\mathrm{i}}=\overrightarrow{\mathrm{G}} \cdot \mathrm{b}_{\mathrm{C}_{\mathrm{i}}}$, $\mathrm{i}=1,2,3$.

Здесь, $\quad \mathrm{b}_{\overrightarrow{\mathrm{C}}_{1}}=\cos \delta \simeq 1, \quad \mathrm{~b}_{\overrightarrow{\mathrm{C}}_{2}}=\sin \delta \cos \beta, \quad \mathrm{b}_{\overrightarrow{\mathrm{C}}_{3}}=\sin \delta \sin \beta$, $\mathrm{b}_{\overrightarrow{\mathrm{C}}_{1}}^{2}+\mathrm{b}_{\overrightarrow{\mathrm{C}}_{2}}^{2}+\mathrm{b}_{\mathrm{G}_{3}}^{2}=1$.

Измерения производятся при нескольких температурах в КТХ стенда, перекрывающих заданный диапазон температур.

Перед началом измерений КТХ стенда выводится на заданную температуру, затем ИИБ в выключенном состоянии выдерживается при
Since all components of the errors are independent, the total error of the elements of the accelerometer orientation matrix can easily be calculated by the formula.

Let's consider each of the components separately.

\section{METHODS OF DETERMINING THE MEASURING AXES ORIENTATION MATRIX OF ACCELEROMETERS, INSTRUMENTAL AND METHODOLOGICAL ERRORS}

Determination of the Ca orientation matrix of the measuring axes of accelerometers in the orthogonal $\mathrm{X}$, $\mathrm{Y}, \mathrm{Z}$ coordinate system, associated with the IMU mounting surfaces, is carried out from the measurements of the output signals from the accelerometers on a high-precision biaxial bench equipped with a heating and cooling chamber (HCC). The normal to the mounting platform of the bench coincides with the axis of the stand. Axis 2 of the bench is orthogonal to axis 1 and is located horizontally. The bench is installed in such a way that at zero angles specified for both axes of the bench, axis 1 is directed upwards, and axis 2 is in the horizontal plane. The IMU is placed and rigidly fixed on the mounting platform of the bench with the help of the precision tooling so that the $\mathrm{Y}$ axis of the IMU coincides with the axis of the bench, and the $\mathrm{X}$ axis with axis 2 (Fig. 1, position $\mathrm{Y}_{\mathrm{a}}$ ). With the help of rotations to $90^{\circ}$ and $180^{\circ}$ relative to axes 1 and 2 , the biaxial bench allows implementing 12 positions of the IMU shown in Fig. 1. Due to errors in setting the bench, the vector of apparent acceleration $\vec{G}$ due to gravity is projected on the axis of the orthogonal coordinate system of the IMU, as shown in Fig. 1 under each of the IMU positions, where [-]T is the operation of the transposition of the vector [?], where $\overrightarrow{\mathrm{C}}_{\mathrm{i}}=\overrightarrow{\mathrm{C}} \cdot \mathrm{b}_{\mathrm{C}_{\mathrm{i}}}, \mathrm{i}=1,2,3$.

Here $\quad b_{\overline{\mathrm{C}}_{1}}=\cos \delta \simeq 1, \quad \mathrm{~b}_{\overline{\mathrm{C}}_{2}}=\sin \delta \cos \beta, \quad \mathrm{b}_{\overline{\mathrm{C}}_{3}}=\sin \delta \sin \beta$, $\mathrm{b}_{\overline{\mathrm{C}}_{1}}^{2}+\mathrm{b}_{\overline{\mathrm{C}}_{2}}^{2}+\mathrm{b}_{\overline{\mathrm{C}}_{3}}^{2}=1$.

Measurements are made at several temperatures in the HCC of the bench, overlapping a predetermined temperature range.

Before the measurements are taken, the HCC of the stand is adjusted to the set temperature, then the IMU in the off state is exposed at this temperature until it reaches all the components of the IMU, after which the power supply is fed to the IMU. In the enabled state, the IMU is additionally exposed until the accelerometers reach the stationary temperature regime.

Measurements are made when the IMU is stationary, sequentially in all 12 positions shown in Fig. In this case, the average values of the voltages at 


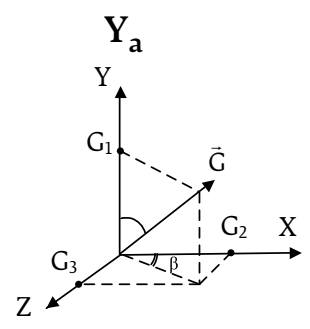

$\overrightarrow{\mathrm{C}}=\left[\begin{array}{lll}\mathrm{G}_{2} & \mathrm{G}_{1} & \mathrm{G}_{3}\end{array}\right]^{\mathrm{T}}$

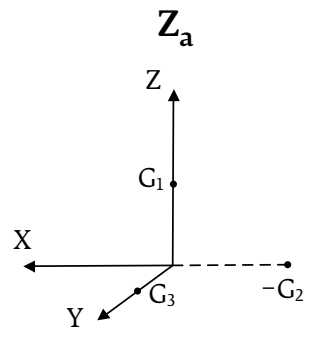

$\overrightarrow{\mathrm{C}}=\left[\begin{array}{lll}-\mathrm{C}_{2} & \mathrm{C}_{3} & \mathrm{G}_{1}\end{array}\right]^{\mathrm{T}}$

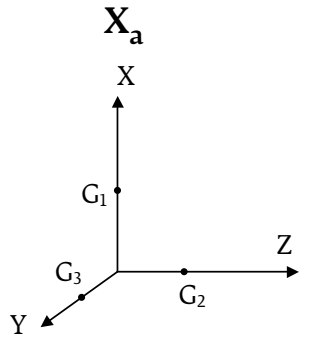

$\overrightarrow{\mathrm{G}}=\left[\begin{array}{lll}\mathrm{C}_{1} & \mathrm{C}_{3} & \mathrm{C}_{2}\end{array}\right]^{\mathrm{T}}$

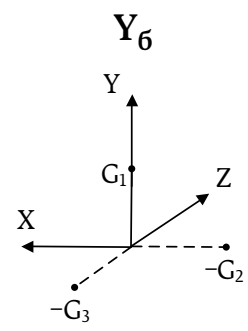

$\overrightarrow{\mathrm{C}}=\left[\begin{array}{lll}-\mathrm{C}_{2} & \mathrm{C}_{1} & -\mathrm{C}_{3}\end{array}\right]^{\mathrm{T}}$

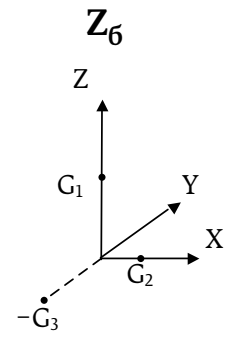

$\overrightarrow{\mathrm{C}}=\left[\mathrm{C}_{2}-\mathrm{C}_{3} \mathrm{G}_{1}\right]^{\mathrm{T}}$

$\mathrm{X}_{6}$

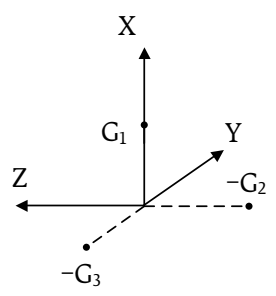

$\overrightarrow{\mathrm{G}}=\left[\mathrm{G}_{1}-\mathrm{G}_{3}-\mathrm{C}_{2}\right]^{\mathrm{T}}$

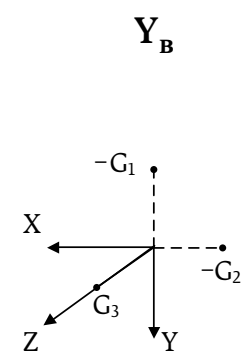

$\overrightarrow{\mathrm{C}}=\left[\begin{array}{lll}-\mathrm{C}_{2} & -\mathrm{G}_{1} & \mathrm{C}_{3}\end{array}\right]^{\mathrm{T}}$

$\mathbf{Z}_{\mathbf{B}}$

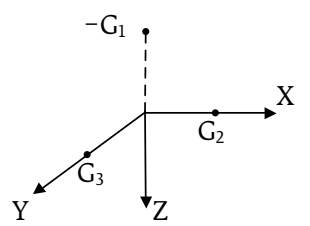

$\overrightarrow{\mathrm{C}}=\left[\begin{array}{lll}\mathrm{G}_{2} & \mathrm{G}_{3} & -\mathrm{G}_{1}\end{array}\right]^{\mathrm{T}}$

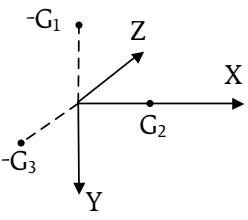

$\overrightarrow{\mathrm{C}}=\left[\mathrm{C}_{2}-\mathrm{C}_{1}-\mathrm{C}_{3}\right]^{\mathrm{T}}$

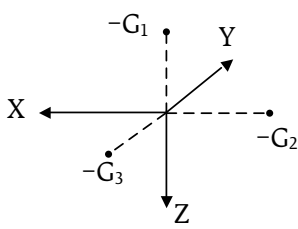

$\overrightarrow{\mathrm{C}}=\left[\begin{array}{lll}-\mathrm{C}_{2} & -\mathrm{C}_{3} & -\mathrm{G}_{1}\end{array}\right]^{\mathrm{T}}$

$$
\mathrm{X}_{\Gamma}
$$

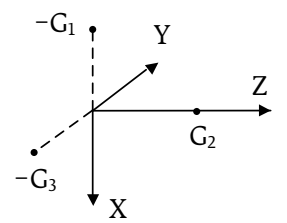

$$
\overrightarrow{\mathrm{C}}=\left[-\mathrm{C}_{1} \mathrm{C}_{3}-\mathrm{C}_{2}\right]^{\mathrm{T}}
$$

Puс. 1. Положения системы координат ИИБ дяя экспериментального определения матрицы ориентации измерительных осей акселерометров

Fig. 1. The positions of the IMU coordinate system for the experimental determination of the orientation matrix of the measuring axes of accelerometers

этой температуре до ее достижения всеми составными частями ИИБ, после чего на ИИБ подается питание. Во включенном состоянии ИИБ дополнительно выдерживается до тех пор, пока акселерометры не достигнут стационарного температурного режима.

Измерения производятся при неподвижном состоянии ИИБ, последовательно во всех 12-ти положениях, показанных на рис.1. При этом the output of the accelerometers are determined in each position $\mathrm{W}_{\mathrm{x}}^{\psi}, \mathrm{W}_{\mathrm{y}}^{\psi}, \mathrm{W}_{\mathrm{z}}^{\psi}$, where $\psi$ is the position of the IMU, $\psi=\mathrm{Y}_{\mathrm{a}}, \mathrm{Y}_{\mathrm{b}}, \ldots$; the subscript $\mathrm{x}, \mathrm{y}, \mathrm{z}$ indicates the measuring axis of the accelerometers. Furthermore, using temperature sensors installed in each of the accelerometers, the corresponding temperature values $\mathrm{T}_{\mathrm{x}}^{\psi}, \mathrm{T}_{\mathrm{y}}^{\psi}, \mathrm{T}_{\mathrm{z}}^{\psi}$ are determined in each of the 12 positions, and then the average temperature 
в каждом положении определяются средние значения напряжений на выходе акселерометров $\mathrm{W}_{\mathrm{x}}^{\psi}, \mathrm{W}_{\mathrm{y}}^{\psi}, \mathrm{W}_{\mathrm{z}}^{\psi}$, где $\psi$ обозначает положение ИИБ $\psi=\mathrm{Y}_{\mathrm{a}}, \mathrm{Y}_{\mathrm{b}}, \ldots$; нижний индекс $\mathrm{x}, \mathrm{y}, \mathrm{z}$ указывает на измерительную ось акселерометров. Кроме того, при помощи температурных датчиков, установленных в каждом из акселерометров, определяются соответствующие значения температуры $\mathrm{T}_{\mathrm{x}}^{\psi}, \mathrm{T}_{\mathrm{y}}^{\psi}, \mathrm{T}_{\mathrm{z}}^{\psi}$ в каждом из 12-ти положений, а затем среднее значение температуры, усредненное по всем акселерометрам, а также по всем 12-ти положениям.

При фиксированной температуре в КТХ стенда в режиме термостатирования напряжения на выходе акселерометров удовлетворяют следующим уравнениям:

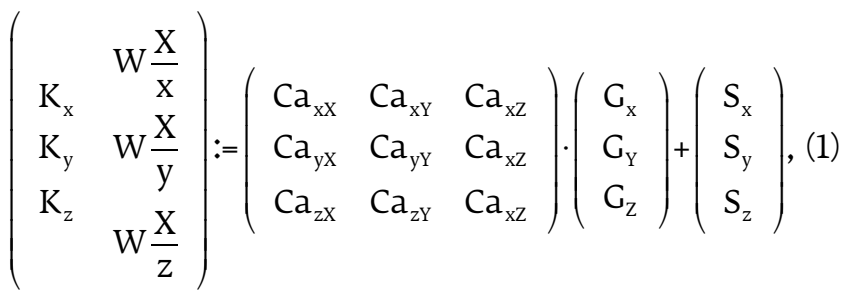

где $\mathrm{K}_{\mathrm{x}}, \mathrm{K}_{\mathrm{y}}, \mathrm{K}_{\mathrm{z}}$ - постоянные для всех 12-ти положений значения масштабных коэффициентов акселерометров, связывающих напряжения на выходе каждого из них с измеряемым кажущимся ускорением на оси чувствительности;

$\mathrm{S}_{\mathrm{x}}, \mathrm{S}_{\mathrm{y}}, \mathrm{S}_{\mathrm{z}}$ - постоянные для всех 12-ти положений значения смещений нулей акселерометров;

$\mathrm{G}_{\mathrm{x}}, \mathrm{G}_{\mathrm{y}}, \mathrm{G}_{\mathrm{z}}$ - проекции измеряемого кажущегося ускорения, обусловленного силой тяжести; value averaged over all accelerometers, as well as over all 12 positions.

At a fixed temperature in the HCC of the stand in the thermostating mode, the voltage at the output of the accelerometers is satisfied by the following equations:

$$
\left(\begin{array}{cc}
\mathrm{K}_{\mathrm{x}} & \mathrm{W} \frac{\mathrm{X}}{\mathrm{X}} \\
\mathrm{K}_{\mathrm{y}} & \mathrm{W} \frac{\mathrm{X}}{\mathrm{y}} \\
\mathrm{K}_{\mathrm{z}} & \mathrm{W} \frac{\mathrm{X}}{\mathrm{z}}
\end{array}\right):=\left(\begin{array}{ccc}
\mathrm{Ca}_{\mathrm{xX}} & \mathrm{Ca}_{\mathrm{xY}} & \mathrm{Ca}_{\mathrm{xZ}} \\
\mathrm{Ca}_{\mathrm{yx}} & \mathrm{Ca}_{\mathrm{yY}} & \mathrm{Ca}_{\mathrm{xZ}} \\
\mathrm{Ca}_{\mathrm{zX}} & \mathrm{Ca}_{\mathrm{zY}} & \mathrm{Ca}_{\mathrm{xZ}}
\end{array}\right) \cdot\left(\begin{array}{c}
\mathrm{G}_{\mathrm{x}} \\
\mathrm{G}_{\mathrm{Y}} \\
\mathrm{G}_{\mathrm{Z}}
\end{array}\right)+\left(\begin{array}{c}
\mathrm{S}_{\mathrm{x}} \\
\mathrm{S}_{\mathrm{y}} \\
\mathrm{S}_{\mathrm{z}}
\end{array}\right),(1)
$$

where $\mathrm{K}_{\mathrm{x}}, \mathrm{K}_{\mathrm{y}}, \mathrm{K}_{\mathrm{z}}$ are constants for all 12 positions of the scale factor values of the accelerometers, connecting the output voltages of each of them with the measured apparent acceleration on the sensitivity axis;

$\mathrm{S}_{\mathrm{x}}, \mathrm{S}_{\mathrm{y}}, \mathrm{S}_{\mathrm{z}}$ are constants for all 12 positions of the zero offset values of the accelerometers; $\mathrm{G}_{\mathrm{x}}, \mathrm{G}_{\mathrm{y}}, \mathrm{G}_{\mathrm{z}}-$ are the projections of the measured apparent acceleration due to gravity;

$\mathrm{Ca}:=\left(\begin{array}{lll}\mathrm{Ca}_{\mathrm{xX}} & \mathrm{Ca}_{\mathrm{xY}} & \mathrm{Ca}_{\mathrm{xz}} \\ \mathrm{Ca}_{\mathrm{yx}} & \mathrm{Ca}_{\mathrm{yY}} & \mathrm{Ca}_{\mathrm{xz}} \\ \mathrm{Ca}_{\mathrm{zX}} & \mathrm{Ca}_{\mathrm{zY}} & \mathrm{Ca}_{\mathrm{xz}}\end{array}\right) \begin{aligned} & \text { is the matrix of } \\ & \text { directional cosines to } \\ & \text { be determined }\end{aligned}$ defining the orientation of the axes of sensitivity of accelerometers in the orthogonal instrumental coordinate system; furthermore, the sum of squares of elements in each row of this matrix is equal to one.

Solving the system of equations (7) with respect to the elements of the matrix $\mathrm{Ca}$, we obtain: 


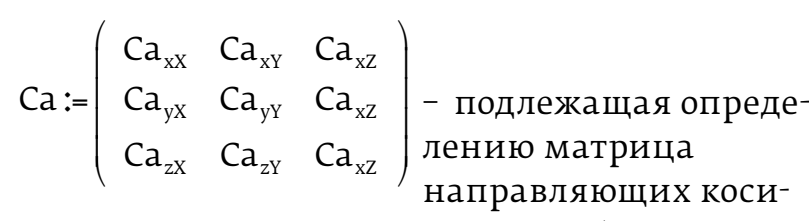
нусов, задающая ориентацию осей чувствительности акселерометров в ортогональной приборной системе координат; при этом сумма квадратов элементов в каждой строке этой матрицы равна единице.

Разрешая систему уравнений (7) отностительно элементов матрицы Са, получим:

$$
\mathrm{Ca}_{\alpha \beta}:=\frac{\mathrm{W} \frac{\beta}{\alpha}}{\sqrt{\left(\mathrm{W} \frac{\mathrm{X}}{\alpha}\right)^{2}+\left(\mathrm{W} \frac{\mathrm{Y}}{\alpha}\right)^{2}+\left(\mathrm{W} \frac{\mathrm{Z}}{\alpha}\right)^{2}}} .
$$

Ошибки определения элементов матрицы ориентации измерительных осей акселерометров в системе координат ИИБ обусловлены погрешностями установки стенда, позиционирования его платформы, биениями осей вращения и наличием шумов на выходе акселерометров. Согласно (10), (11) ошибка при определении элемента $\mathrm{Ca}_{\alpha \beta}$ может быть представлена в виде:

$\Delta \mathrm{Ca}_{\alpha \beta}:=\frac{\mathrm{K}_{\alpha}\left[\left(\Delta \mathrm{W} \frac{\beta \mathrm{à}}{\alpha}\right)+\left(\Delta \mathrm{W} \frac{\beta \mathrm{á}}{\alpha}\right)-\left(\Delta \mathrm{W} \frac{\beta \hat{\mathrm{a}}}{\alpha}\right)-\left(\Delta \mathrm{W} \frac{\beta \tilde{\mathrm{a}}}{\alpha}\right)\right]}{4 \mathrm{C}_{1}}, \alpha \neq \beta$.

При использовании высокоточного стенда (с малыми среднеквадратическими значениями ошибок позиционирования $\sigma_{1}$ и биений оси $\left.\sigma_{2}\right)$, считая угловые погрешности его установки относительно местной вертикали $\delta$ малыми, принимая все четыре слагаемых в числителе (3) статически независимыми, а шумовую составляющую на выходе акселерометров - белым шумом с интенсивностью Q, взяв длительность измерений в каждом из 12-ти положений равной $\tau$ секунд, получим в линейном приближении оценку для среднеквадратического значения угловой погрешности (измеренную в угловых секундах):

$$
\sigma_{\phi \alpha \beta}:=2 \cdot \sqrt{\left[\frac{\left(\mathrm{K} \frac{2}{\alpha}\right) \cdot 180}{\mathrm{G}^{2} \cdot \tau}\right] \cdot \frac{3600}{\pi}+\left(\sigma_{1}\right)^{2}+\left(\sigma_{2}\right)^{2}}
$$

$$
\mathrm{Ca}_{\alpha \beta}:=\frac{\mathrm{W} \frac{\beta}{\alpha}}{\sqrt{\left(\mathrm{W} \frac{\mathrm{X}}{\alpha}\right)^{2}+\left(\mathrm{W} \frac{\mathrm{Y}}{\alpha}\right)^{2}+\left(\mathrm{W} \frac{\mathrm{Z}}{\alpha}\right)^{2}}} .
$$

The errors in determining the elements of the orientation matrix of the measuring axes of accelerometers in the coordinate system of the IMU are due to errors in setting the bench, positioning its platform, wobble of the rotation axes and the presence of noises at the accelerometers. According to (10), (11) the error in determining the element $\mathrm{Ca}_{\alpha \beta}$ can be represented in the form:

$\Delta C a_{\alpha \beta}:=\frac{K_{\alpha}\left[\left(\Delta W \frac{\beta \grave{a}}{\alpha}\right)+\left(\Delta W \frac{\beta a ́}{\alpha}\right)-\left(\Delta W \frac{\beta \hat{a}}{\alpha}\right)-\left(\Delta W \frac{\beta \tilde{a}}{\alpha}\right)\right]}{4 G_{1}}, \alpha \neq \beta$.

When using a high-precision bench (with small mean square errors of positioning $\sigma_{1}$ and wobble of the axis $\sigma_{2}$ ), small angular errors of its setting relative to the local vertical $\delta$, taking all four additive components in (3) as statically independent, and the noise component at the output of the accelerometers as a white noise with intensity $Q$, the duration of measurements in each of the 12 positions equal to $\tau s$, in the linear approximation we obtain an estimate for the root-mean-square value of the angular error in the angular seconds:

$$
\sigma_{\phi \alpha \beta}:=2 \cdot \sqrt{\left[\frac{\left(\mathrm{K} \frac{2}{\alpha}\right) \cdot 180}{\mathrm{G}^{2} \cdot \tau}\right] \cdot \frac{3600}{\pi}+\left(\sigma_{1}\right)^{2}+\left(\sigma_{2}\right)^{2}}
$$

For example, for $\mathrm{K}_{\alpha}=\mathrm{G}, \mathrm{Q}=3 \cdot 10^{-9} \mathrm{~B}^{2} \cdot \mathrm{c}, \tau=30 \mathrm{c}, \sigma_{1}=5^{\prime \prime}$, $\sigma_{2}=2^{\prime \prime}$ this value is equal to $11,52^{\prime \prime}$.

The orientation matrix of the measuring axes and the corresponding average value of the temperature of the accelerometers (4) experimentally found for each temperature in the HCC of the bench are used to investigate the temperature dependence of this matrix.

\section{TEMPERATURE CHANGES IN THE MEASURING AXES ORIENTATION OF ACCELEROMETERS, PHYSICAL CAUSES AND COMPENSATION METHODS}

Let's refer to the IMU design. There are two options for placing accelerometers (Fig. 2a, b). In the first case, the accelerometers are located on the same frame 
Например, при $\mathrm{K}_{\alpha}=\mathrm{C}$, $\mathrm{Q}=3 \cdot 10^{-9} \mathrm{~B}^{2} \cdot \mathrm{c}, \tau=30 \mathrm{c}, \sigma_{1}=5^{\prime \prime}, \sigma_{2}=2^{\prime \prime}$ это значение равно 11,52".

Экспериментально найденная для каждой из температур в KTX стенда матрица ориентации измерительных осей и соответствующее среднее значение температуры акселерометров (4) используются для исследования температурной зависимости этой матрицы.

\section{ТЕМПЕРАТУРНЫЕ \\ ИЗМЕНЕНИЯ \\ ОРИЕНТАЦИИ \\ ИЗМЕРИТЕЛЬНЫХ ОСЕЙ \\ АКСЕЛЕРОМЕТРОВ, ФИЗИЧЕСКИЕ ПРИЧИНЫ И МЕТОДЫ ПАРИРОВАНИЯ}

Обратимся к конструкции ИиБ. Существует два варианта размещения акселерометров (рис.2a, b). В первом случае акселерометры располагаются на одной раме с гироскопами. Считается, что при этом температурные изменения матрицы ориентации гироскопов и акселерометров будут одинаковыми, и их легче описать некоторой функцией, зависящей от температуры. Однако при такой установке в случае поломки гироскопа или акселерометра потребуется разбирать и соответственно заново проводить аттестацию всего ИИБ. Кроме того, тепловыделение в гироскопе в 17 раз превышает тепловыделение в акселерометре (2,5 Вт против 0,15 Вт), что приводит к дополнительному перегреву акселерометров и соответственно большим смещениям нуля и масштабного коэффициента [3].

Во втором случае акселерометры расположены в отдельном модуле, что обеспечивает их меньший перегрев и возможность раздельного ремонта блоков гироскопов и акселерометров $[4,5]$. Однако казалось бы, что в такой конструкции температурные изменения матриц ориентации акселерометров должны стать большими из-за введения дополнительного болтового соединения. Механическая прочность Ииь должна также уменьшиться. Задачей данного исследования являлось доказательство или опровержение этих гипотез.

Температурные изменения ориентации измерительных осей акселерометров складываются из трех частей: with the gyroscopes. It is believed that in this case the temperature changes in the orientation matrix of gyroscopes and accelerometers will be the same and they are easier to describe by any function of temperature. However, with such an arrangement, in the event of breakage of a gyroscope or an accelerometer, it will be necessary to disassemble and, accordingly, re-calibrate the entire IMU. Furthermore, the heat in the gyroscope is 17 times higher than the heat release in the accelerometer $(2.5 \mathrm{~W}$ vs. $0.15 \mathrm{~W})$, which leads to an additional overheating of the accelerometers and therefore to large zero and scale shifts [3].

In the second case, the accelerometers are located in a separate module which ensures less overheating and the possibility of separate repair of gyroscope blocks and accelerometers $[4,5]$. However, the temperature changes in the orientation matrices of the accelerometers would seem to become greater due to the introduction of an additional bolted connection. The mechanical strength of the IMU should also decrease. The task of this study was to prove or disprove these hypotheses.

Temperature changes in the measuring axes orientation of accelerometers are made up of three parts:

1. Change the orientation angle of the measuring axis of the accelerometer relative to its mounting plane $\Delta \mathrm{Ca}_{\mathrm{Ta}}$.

2. Change in the position of the mounting surfaces of the body parts of the IMU, on which accelerometers are installed $\Delta \mathrm{Ca}_{T_{\Pi}}$.

3. Error of temperature correction $\Delta \mathrm{Ca}_{\mathrm{TK}}$. 
Таблица 1. Величины $\Delta \mathrm{Ca}_{\text {Та }}$ для акселерометров различных типов Table 1. Values $\triangle \mathrm{Ca}_{\mathrm{Ta}}$ for accelerometers of various types

\begin{tabular}{|c|c|c|c|c|c|c|c|}
\hline $\begin{array}{l}\text { Параметры } \\
\text { Parameters }\end{array}$ & A-18 & AK-15 & $\mathrm{BA}-3$ & A-18T & AK-18 & $\begin{array}{l}\text { AAK-02 } \\
(E I)\end{array}$ & QA-3000 \\
\hline $\begin{array}{l}\text { Нестабильность базовой плоскости по оси } \\
\text { чувствительности в течение срока службы } \\
\text { Instability of the reference plane along the } \\
\text { sensitivity axis during the service life }\end{array}$ & \pm 60 & \pm 4 & \pm 20 & \pm 15 & \pm 15 & \pm 20 & $\pm 16,5$ \\
\hline $\begin{array}{l}\text { Диапазон измеряемых ускорений, g } \\
\text { Range of measured accelerations, g }\end{array}$ & \pm 40 & \pm 20 & \pm 50 & \pm 40 & \pm 35 & \pm 50 & \pm 60 \\
\hline $\begin{array}{l}\text { Диапазон рабочих температур,оС } \\
\text { Operating temperature range, }{ }^{\circ} \mathrm{C}\end{array}$ & $-50 \ldots+75$ & $-60 \ldots+70$ & $-55 \ldots+85$ & $-50 \ldots+85$ & $-55 \ldots+75$ & $-55 \ldots+85$ & $-55 \ldots+95$ \\
\hline $\begin{array}{l}\text { Материал маятника } \\
\text { Pendulum material }\end{array}$ & $\begin{array}{l}\text { Кремний } \\
\text { Silicon }\end{array}$ & $\begin{array}{l}\text { Кварц } \\
\text { Quartz }\end{array}$ & $\begin{array}{l}\text { Кремний } \\
\text { Silicon }\end{array}$ & $\begin{array}{l}\text { Кремний } \\
\text { Silicon }\end{array}$ & $\begin{array}{l}\text { Кварц } \\
\text { Quartz }\end{array}$ & $\begin{array}{l}\text { Кварц } \\
\text { Quartz }\end{array}$ & $\begin{array}{l}\text { Кварц } \\
\text { Quartz }\end{array}$ \\
\hline
\end{tabular}

1. Изменение угла ориентации измерительной оси акселерометра относительно своей посадочной плоскости $\Delta \mathrm{Ca}_{\mathrm{Ta}}$.

2. Изменение положения посадочных поверхностей корпусных деталей ИиБ, на которые устанавливаются акселерометры $\Delta \mathrm{Ca}_{\mathrm{Tп}}$.

3. Ошибка температурной коррекции $\Delta \mathrm{Ca}_{\mathrm{TK}}$.

Суммарно температурные уходы направлений измерительных осей акселерометров определяются по формуле:

$$
\Delta \mathrm{Ca}_{\mathrm{T}}=\sqrt{\left(\Delta \mathrm{Ca}_{\mathrm{Ta}}\right)^{2}+\left(\Delta \mathrm{Ca}_{\mathrm{Tn}}\right)^{2}+\left(\Delta \mathrm{Ca}_{\mathrm{TK}}\right)^{2}} .
$$

Величина $\Delta \mathrm{Ca}_{\mathrm{Ta}}$ определяется конструкцией акселерометра, причем температурная зависимость имеет петлю гистерезиса. Величина этого гистерезиса называется нестабильностью базовой плоскости по оси чувствительности в течение срока службы.

Величины $\Delta \mathrm{Ca}_{\mathrm{Ta}}$ для акселерометров различных типов приведены в табл. 1. Из данных видно, что нестабильность базовой плоскости по оси чувствительности определяется не столько материалом маятника, как например смещение нуля [3], а скорее диапазоном измеряемых ускорений и рабочих температур. Особняком стоят весьма низкие характеристики А-18, однако данный прибор был разработан где-то на пять лет раньше своих конкурентов.

Величина $\Delta \mathrm{Ca}_{\text {тп }}$ определяется пластическими деформациями конструкции, вызванными разницей коэффициентов термического расширения корпуса акселерометра $\mathrm{KTP}_{\mathrm{a}}$ и корпусных деталей ИИБ $\mathrm{KTP}_{\mathrm{K}}$. Максимальное значение $\Delta \mathrm{Ca}_{\mathrm{Tп}}$ может быть оценено по формуле:
The total temperature changes in the directions of the measuring axes of accelerometers are determined by the formula:

$$
\Delta \mathrm{Ca}_{\mathrm{T}}=\sqrt{\left(\Delta \mathrm{Ca}_{\mathrm{Ta}}\right)^{2}+\left(\Delta \mathrm{Ca}_{\mathrm{Tn}}\right)^{2}+\left(\Delta \mathrm{Ca}_{\mathrm{TK}}\right)^{2}} .
$$

The value $\Delta \mathrm{Ca}_{\mathrm{Ta}}$ is determined by the design of the accelerometer, the temperature dependence having a hysteresis. The value of this hysteresis is referred to as the instability of the reference plane along the sensitivity axis during the service life.

The values $\Delta \mathrm{Ca}_{\mathrm{Ta}}$ for accelerometers of various types are given in Table. 1, where it is seen that the instability of the reference plane along the sensitivity axis is determined not so much by the material of the pendulum as, e.g., zero displacement [3], but rather by the range of measured accelerations and operating temperatures. A-18 stands out with very low characteristics, but it was developed somewhere for five years ahead of its competitors.

The value $\Delta \mathrm{Ca}_{\mathrm{T}}$ is determined by the plastic deformations of the structure caused by the difference in the coefficients of thermal expansion of the accelerometer body $\mathrm{KTP}_{\mathrm{K}}$ and the IMU body parts $\mathrm{KTP}_{\mathrm{a}}$. The maximum value can be estimated from the formula:

$$
\Delta \mathrm{Ca}_{\mathrm{T \Pi}}=0,1 \cdot\left(\mathrm{KTP}_{\mathrm{K}}-\mathrm{KTP}_{\mathrm{a}}\right)\left(\mathrm{T}_{\max }-\mathrm{T}_{0}\right),
$$

where $T_{\max }$ is the maximum temperature inside the IMU at the accelerometer installation site, $T_{0}$ is the temperature in the normal climatic conditions.

Let's estimate $\triangle \mathrm{Ca}_{\mathrm{T \Pi}}$. The body of the accelerometer is made of steel $\left(\mathrm{KTP}=15 \cdot 10^{-6} 1 /{ }^{\circ} \mathrm{C}\right)$, the IMU body parts are made of $\mathrm{D}-16\left(\mathrm{KTP}=22,9 \cdot 10^{-6} 1 /{ }^{\circ} \mathrm{C}\right), \mathrm{T}_{\max }=+85{ }^{\circ} \mathrm{C}$, $\mathrm{T}_{0}=+20^{\circ} \mathrm{C}, \Delta \mathrm{Ca}_{\mathrm{T \Pi}}=5,1 \cdot 10^{-5} \mathrm{rad} .=11^{\prime \prime}$. 


$$
\Delta \mathrm{Ca}_{\mathrm{T \Pi}}=0,1 \cdot\left(\mathrm{KTP}_{\mathrm{K}}-\mathrm{KTP}_{\mathrm{a}}\right)\left(\mathrm{T}_{\max }-\mathrm{T}_{0}\right),
$$

где $\mathrm{T}_{\max }-$ максимальная температура внутри ииБ в месте установки акселерометров, $\mathrm{T}_{0}-$ тем- $^{-}$ пература НКУ.

Проведем оценку $\Delta \mathrm{Ca}_{\text {тп }}$. Корпус акселерометра изготовлен из стали $\left(\mathrm{KTP}=15 \cdot 10^{-6}\right.$ $\left.1 /{ }^{\circ} \mathrm{C}\right)$, корпусные детали ИИБ изготовлены из Д-16 $\left(\mathrm{KTP}=22,9 \cdot 10^{-6} 1 /{ }^{\circ} \mathrm{C}\right), \mathrm{T}_{\text {мах }}=+85^{\circ} \mathrm{C}, \mathrm{T}_{0}=+20^{\circ} \mathrm{C}$, $\Delta \mathrm{Ca}_{\text {Тп }}=5,1 \cdot 10^{-5}$ рад. $=11^{\prime \prime}$.

Ошибка температурной коррекции $\Delta \mathrm{Ca}_{\mathrm{Tk}}$ определяется точностью измерения температуры $\Delta \mathrm{T}$ и температурным коэффициентом угла отклонения базовой плоскости $\mathrm{K}_{\mathrm{ca}}$ :

$$
\Delta \mathrm{Ca}_{\mathrm{TK}}=\Delta \mathrm{T} \cdot \mathrm{K}_{\mathrm{Ca}} .
$$

Для кварцевых акселерометров $\mathrm{k}_{\mathrm{Ca}} \approx 1,5^{\prime \prime} /{ }^{\circ} \mathrm{C}$, для кремниевых эта величина существенно больше - до $6^{\prime \prime} /{ }^{\circ} \mathrm{C}$. Точность измерения температуры в условиях бортовой аппаратуры (помехи, время измерения) составляет $\Delta \mathrm{T} \approx 0,2{ }^{\circ} \mathrm{C}$. Соответственно $\Delta \mathrm{Ca}_{\mathrm{TK}} \approx 0,3$ для кварцевых акселерометров и до 1,2" для кремниевых.

На основании полученных данных проведем оценку $\Delta \mathrm{Ca}_{\mathrm{T}}$. По формуле (5) получим, что $\Delta \mathrm{Ca}_{\mathrm{T}} \approx 12-19 "$ для кварцевых акселерометров, против $\Delta \mathrm{Ca}_{\mathrm{T}} \approx 19-61^{\prime \prime}$ для кремниевых акселерометров. Таким образом, величина $\Delta \mathrm{Ca}_{\mathrm{T}}$ практически полностью определяется применяемым типом акселерометра.

Сравним полученные расчетные значения с результатами эксперимента. На рис.3a, b показана измеренная зависимость углов ориентации измерительных осей акселерометров относительно ортогональной системы координат $A_{\text {ииь }}$ от температуры для двух типов акселерометров и одной и той же конструкции ИиБ (рис. 2b). Для сравнения на графике приведены температурные зависимости углов ориентации аналогичных измерительных осей гироскопов и разности между ними. Это позволяет определить как общие угловые поводки конструкции ииБ (они одинаковы для гироскопов и акселерометров), так и изменения ориентации каждого из инерциальных датчиков отдельно.

Как видно из рис.3a, b температурная зависимость углов ориентации гироскопов очень слабая. Синхронная составляющая температурного изменения углов ориентации и угловые поводки конструкции ИИБ отсутствуют. Температурная

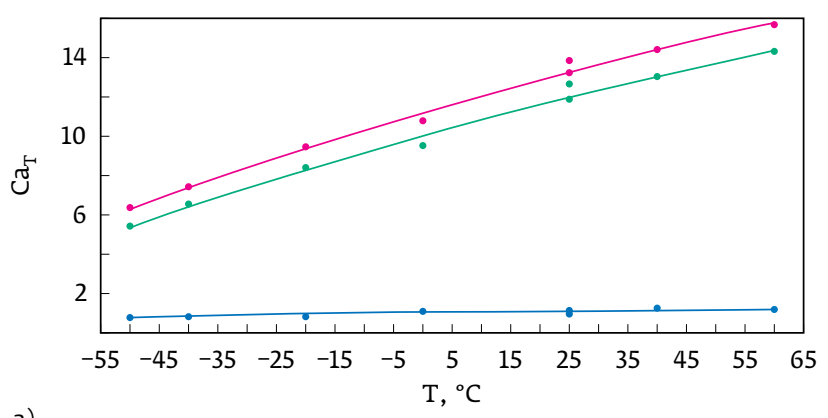

a)

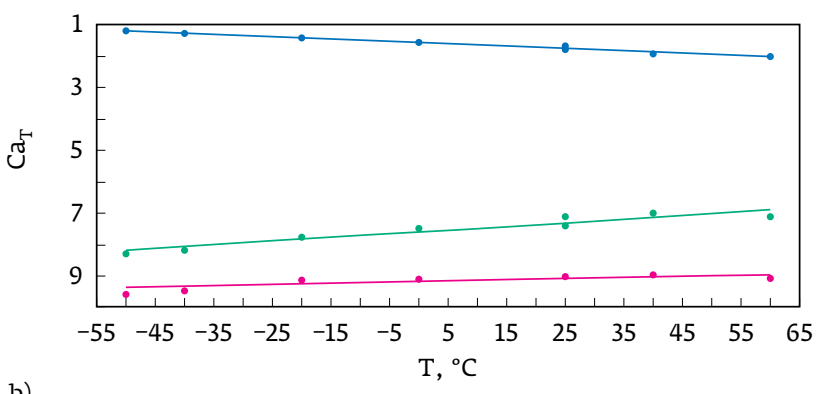

b)

— Температурная зависимость углов ориентации
акселерометров
— Температурная зависимость углов ориентации
гироскопов
— Температурная зависимость разницы между углами
ориентации акселерометров и гироскопов

Puc. 3 Температурная зависимость углов ориентации гироскопов и акселерометров: а) кремниевый акселерометр А-18; b) кварцевый акселерометр АК-18

Fig. 3 Temperature dependence of the orientation angles of gyroscopes and accelerometer: (a) silicon accelerometer A-78; (b) quartz accelerometer AK-18

The error of the temperature correction $\Delta \mathrm{Ca}_{\mathrm{TK}}$ is determined by the accuracy of the temperature measurement $\Delta \mathrm{T}$ and the temperature coefficient of the deflection angle of the reference plane $\mathrm{k}_{\mathrm{ca}}$ :

$$
\Delta \mathrm{Ca}_{\mathrm{TK}}=\Delta \mathrm{T} \cdot \mathrm{k}_{\mathrm{Ca}} .
$$

For quartz accelerometers, $\mathrm{k}_{\mathrm{Ca}} \approx 1.5^{\prime \prime} /{ }^{\circ} \mathrm{C}$, for silicon, this value is much larger - up to $6^{\prime \prime} /{ }^{\circ} \mathrm{C}$. The accuracy of temperature measurement in the conditions of on-board equipment (interference, measurement time) is $\Delta \mathrm{T} \approx 0,2^{\circ} \mathrm{C}$. Accordingly, $\Delta \mathrm{Ca}_{\mathrm{TK}} \approx 0,3^{\prime \prime}$ for quartz accelerometers and up to $1.2^{\prime \prime}$ for silicon ones.

Based on the data obtained, we will estimate $\Delta \mathrm{Ca}_{\mathrm{T}}$. Using formula (5), we obtain $\Delta \mathrm{Ca}_{\mathrm{T}} \approx 12-19 "$ for quartz accelerometers, against $\Delta \mathrm{Ca}_{\mathrm{T}} \approx 19-61^{\prime \prime}$ for silicon accelerometers. Thus, the value $\Delta \mathrm{Ca}_{\mathrm{T}}$ is almost 
Таблица 2. Сводные результаты эксперимента по определению температурных уходов направлений измерительных осей акселерометров

Table 2. Summary results of the experiment for determining the temperature drifts of the directions of the accelerometer measuring axes

\begin{tabular}{|c|c|c|}
\hline $\begin{array}{l}\text { Параметр } \\
\text { Parameter }\end{array}$ & $\begin{array}{l}\text { Кремниевый } \\
\text { акселерометр A-18 } \\
\text { Silicon } \\
\text { acelerometer A-18 }\end{array}$ & $\begin{array}{l}\text { Кварцевый } \\
\text { акселерометр АК-18 } \\
\text { Quartz } \\
\text { acelerometer AK-18 }\end{array}$ \\
\hline $\begin{array}{l}\text { Максимальное значение углов отклонения измерительной оси акселерометра } \\
\text { Maximum value of the deviation angles of the accelerometer measuring axis }\end{array}$ & $14,5^{\prime}\left(30^{\prime}\right)$ & $8,5^{\prime}\left(20^{\prime}\right)$ \\
\hline $\begin{array}{l}\text { Температурный коэффициент угла отклонения базовой плоскости } \\
\text { Temperature coefficient of the deviation angle of the reference plane }\end{array}$ & $4,9^{\prime \prime} /{ }^{\circ} \mathrm{C}\left(6^{\prime \prime} /{ }^{\circ} \mathrm{C}\right)$ & $0,8^{\prime \prime} /{ }^{\circ} \mathrm{C}\left(1,5^{\prime \prime} /{ }^{\circ} \mathrm{C}\right)$ \\
\hline $\begin{array}{l}\text { Температурные уходы направлений измерительных осей акселерометров } \\
\text { Температурные уходы направлений измерительных осей акселерометров }\end{array}$ & $35^{\prime \prime}(60 ")$ & $11,5^{\prime \prime}\left(15^{\prime \prime}\right)$ \\
\hline
\end{tabular}

зависимость углов ориентации кремниевых акселерометров очень сильная.

Для кварцевых акселерометров зависимости сравнимы с функциями для гироскопов, что опять же доказывает главенство материала маятника в этом вопросе.

Теперь обратимся к эффективности термокоррекции. На рис.4a, b приведены зависимости $\Delta \mathrm{Ca}_{\mathrm{T}}$ для обоих типов акселерометров. В табл. 2 представлены сводные результаты эксперимента. В скобках приведены расчетные данные по техническим спецификациям акселерометров.

Как видно из рис.3, 4 и табл. 2, температурные сдвиги направлений измерительных осей акселерометров $\Delta \mathrm{Ca}_{\mathrm{T}}$ полностью определяются величиной $\Delta \mathrm{Ca}_{\mathrm{Ta}}$, что соответствует выводам из формулы (5). Конструктивное расположение акселерометров в ИИБ не влияет на температур ную погрешность положения измерительных осей акселерометров.

\section{ИЗМЕНЕНИЯ НАПРАВЛЕНИЙ ИЗМЕРИТЕЛЬНЫХ ОСЕЙ АКСЕЛЕРОМЕТРОВ ПОСЛЕ МЕХАНИЧЕСКИХ ВОЗДЕЙСТВИЙ}

В процессе эксплуатации ИИБ подвергается механическим ударам и вибрациям, которые также приводят к изменению ориентации изме рительных осей акселерометров. Определить изменения направлений измерительных осей акселерометров непосредственно в момент меха нических воздействий не представляется воз можным, поэтому о механической устойчивости акселерометров судят по изменению ориентации измерительных осей после механических ударов и вибраций. completely determined by the type of accelerometer used.

Let's compare the calculated values obtained with the experiment's results. Fig. 3a, b shows the measured dependence of the orientation angles of the measuring axes of accelerometers relative to the orthogonal coordinate system $A_{I M U}$ on the temperature for two types of accelerometers and the same design of the IMU (Fig. 2b). For comparison,

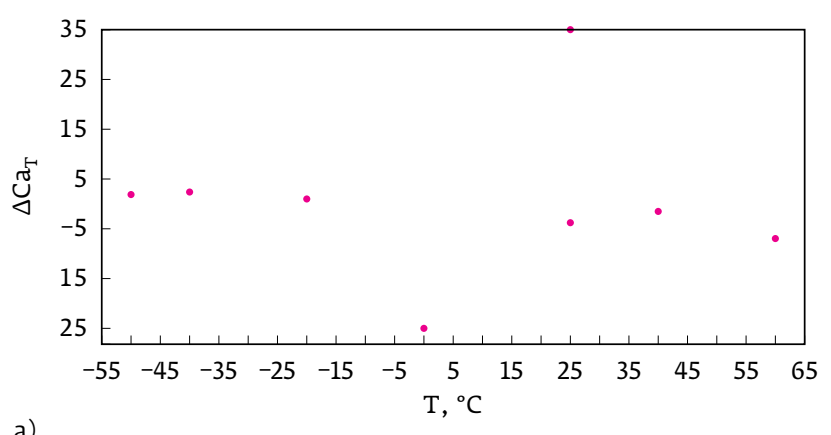

a)

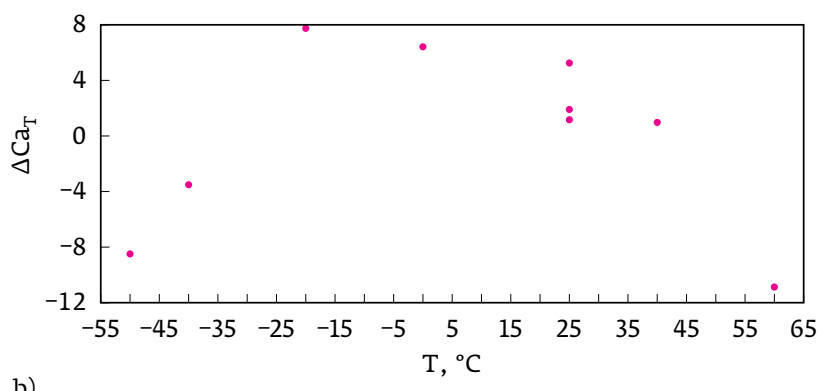

b)

Puс 4. Зависимости $\Delta \mathrm{Ca}_{\mathrm{T}}$ от температуры окружающей среды: (а) кремниевый акселерометр А-18; (b) кварцевый акселерометр АК-18

Fig. 4. Dependences $\triangle \mathrm{Ca}_{\mathrm{T}}$ for ambient temperature: (a) silicon accelerometer A-18; (b) quartz accelerometer AK-18 
Таблица 3. Величины уходов матриц направляющих косинусов измерительных осей гироскопов и акселерометров после механических воздействий

Table 3. The values of the matrices drifts of the direction cosine of the gyroscopes and accelerometers measuring axes after mechanical exposures

\begin{tabular}{|c|c|c|c|c|c|c|c|}
\hline \multirow{3}{*}{\multicolumn{2}{|c|}{$\begin{array}{l}\text { Гироскоп или } \\
\text { акселерометр } \\
\text { Gyroscope or } \\
\text { acelerometer }\end{array}$}} & \multicolumn{6}{|c|}{ Exposure / Воздействие } \\
\hline & & \multicolumn{3}{|c|}{$\begin{array}{c}\text { Одиночные удары } \\
\text { Single impacts }\end{array}$} & \multicolumn{3}{|c|}{$\begin{array}{l}\text { Синусоидальная вибрация } \\
\text { Sinusoidal vibration }\end{array}$} \\
\hline & & $20 G$ & $40 G$ & $100 G$ & $5 G$ & $10 G$ & $20 G$ \\
\hline \multirow{3}{*}{$\begin{array}{l}\text { Уход } \overline{\mathrm{C}} \mathrm{q}, \\
\text { угл. с } \\
\text { Drift } \overline{\mathrm{C}} \mathrm{q}, \\
\text { angle. s }\end{array}$} & $x Y$ & 8,03 & 11,7 & 0,13 & $-2,37$ & $-0,41$ & $-33,38$ \\
\hline & $x Z$ & 0,89 & 1,25 & 24,14 & $-9,05$ & $-2,57$ & 17,76 \\
\hline & $y z$ & $-0,51$ & 5,52 & 7,78 & $-4,86$ & $-0,51$ & 22,09 \\
\hline \multirow{3}{*}{ 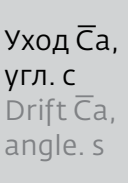 } & $x Y$ & $-9,70$ & $-8,25$ & 0,25 & 12,49 & $-3,70$ & 13,83 \\
\hline & $x Z$ & $-9,34$ & $-7,44$ & $-0,57$ & 15,49 & $-7,35$ & 9,76 \\
\hline & $y z$ & $-0,81$ & $-0,60$ & $-0,42$ & 1,75 & $-0,08$ & $-51,34$ \\
\hline
\end{tabular}

the plot shows the orientation angles of similar measuring axes of gyroscopes and the difference between them. This allows us to determine how the common angular levers of the IMU design (they are the same for gyroscopes and accelerometers), and the orientation changes of each of the inertial sensors separately.

As can be seen from Fig. 3a, b, the temperature dependence of the orientation angles of gyroscopes is very weak. The synchronous component of the temperature change in the orientation angles and angular levers of the IMU design is absent. The temperature dependence of the orientation

Для исследования изменения направления измерительных осей акселерометров ИиБ с акселерометром А-18 после механических воздействий, он был подвергнут одиночным ударам с ускорением $20 \mathrm{~g}, 40 \mathrm{~g}, 100 \mathrm{~g}$ в количестве 4-х ударов, а также синусоидальной вибрации с часто- angles of silicon accelerometers is very strong.

For quartz accelerometers, the dependencies are comparable to the functions for gyroscopes, which again, proves the dominance of the pendulum material in this matter. 
той 25 Гц и амплитудой $5 \mathrm{~g}, 10 \mathrm{~g}$ и 20g, продолжительностью 10 мин. Каждое воздействие проводилось в направлении каждой из осей ИИБ $(\mathrm{X}, \mathrm{Y}, \mathrm{Z})$. До, между и после воздействий были измерены матрицы направляющих косинусов

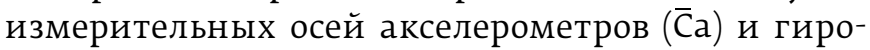
скопов ( $\overline{\mathrm{C}} q)$ на высокоточном трехосном стенде. Ошибка определения углов ориентации составляла, как было уже сказано выше, $\pm 12 "$ по уровню $1 \sigma$ или $\pm 30 "$ Результаты эксперимента приведены в табл. 3.

Результаты эксперимента следующие:

- акселерометры и гироскопы продемонстрировали хорошую прочность к ударам и вибрации.

- $\quad$ за пределы допустимой погрешности эксперимента вышли результаты измерений отклонения оси как по гироскопам, так и по акселерометрам при случайной вибрации с амплитудой $20 \mathrm{~g}$. По-видимому, эта величина определяет предельное воздействие по прочности, выдерживаемое конструкцией гироскопов и акселерометров.

\section{ЗАКЛЮЧЕНИЕ}

Проведенные исследования показали, что изменения матрицы ориентации акселерометров при температурных, ударных, вибрационных воздействиях определяются на 90\% самим акселерометром. В связи с этим установка гироскопов и акселерометров на одни и те же посадочные плоскости корпуса ИИБ не является обязатель ной. Это существенно улучшает ремонтопригод ность ИИБ и уменьшает перегрев акселерометров. Применение термокоррекции матрицы ориентации линейной функцией позволяет уменьшить ошибку до погрешностей акселерометров. Предложенная конструкция ИИБ с раздельным расположением гироскопов и акселерометров также обеспечивает механическую прочность по критерию сохранения ориентации измерительных осей инерциальных датчиков до высоких уровней механических воздействий.

\section{ЛИТЕРАТУРА}

1. Ривкин С. С., Берман 3. М., Окон И. М. Определение параметров ориентации объекта бесплатформенной инерциальной системой. - СПб: ЦнИИ "Электроприбор", 1996, 226 с.

Rivkin S. S., Berman Z. M., Okon I. M. Determining the parameters of the orientation of the object by the strapdown inertial system. St. Petersburg: Central Research Institute "Elektropribor", 1996.

2. Ишлинский А. Ю. Ориентация, гироскопы и инерциальная навигация. - Наука, 1976.
Now let's refer to the efficiency of thermal correction. Fig. 4a, b shows the dependencies $\Delta \mathrm{Ca}_{\mathrm{T}}$ for both types of accelerometers. Table 2 summarizes the results of the experiment. In brackets are the calculated data on the technical specifications of accelerometers.

As can be seen from Fig. 3 and 4 and Table 2, the temperature shifts of the directions of the measuring axes of the accelerometers $\Delta \mathrm{Ca}_{\mathrm{T}}$ are completely determined by the value $\Delta \mathrm{Ca}_{\mathrm{Ta}}$, which corresponds to the conclusions of formula (5). The structural arrangement of the accelerometers in the IMU does not affect the temperature error of the position of the measuring axes of the accelerometers.

\section{CHANGES IN THE DIRECTIONS OF MEASURING AXES OF ACCELEROMETERS AFTER MECHANICAL IMPACT}

In the course of operation, the IMU is subjected to mechanical impacts and vibrations that also lead to a change in the orientation of the measuring axes of the accelerometers. It is not possible to determine the changes in the directions of the measuring axes of accelerometers directly at the moment of mechanical exposures, therefore, the mechanical stability of accelerometers is judged by changing the orientation of the measuring axes after mechanical impacts and vibrations.

To study the change in the direction of the measuring axes of the accelerometers of the IMU with the accelerometer A-18 after mechanical exposures, it was subjected to single shocks with an acceleration of $20 \mathrm{~g}, 40 \mathrm{~g}, 100 \mathrm{~g}$ in the number of 4 impacts, as well as sinusoidal vibration with a frequency of $25 \mathrm{~Hz}$ and an amplitude of $5 \mathrm{~g}, 10 \mathrm{~g}$ and 20g, for 10 minutes. Each exposure was conducted in the direction of each of the axes of the IMU (X, $\mathrm{Y}, \mathrm{Z}$ ). Prior to, between and after the impacts, the matrixes of the direction cosines of the measuring axes of accelerometers $(\overline{\mathrm{C}} \mathrm{a})$ and gyroscopes $(\overline{\mathrm{C}} \mathrm{q})$ were measured on a high-precision triaxial bench. The error in determining the orientation angles was, as was already mentioned, $\pm 12^{\prime \prime}$ for level $1 \sigma$ or \pm 30 ". The results of the experiment are given in Table 3.

The results of the experiment are as follows:

- accelerometers and gyroscopes have demonstrated good strength to impacts and vibrations.

- deviations from both the gyroscopes and the accelerometers for random vibrations with an amplitude of $20 \mathrm{~g}$ appeared beyond 
Ishlinsky A. Y. Orientation, gyroscopes and inertial navigation.Science, 1976

3. Голяев Ю. Д., Колбас Ю. Ю., Коновалов С. Ф., Томилин А. В. Критерии выбора акселерометров для инерциального измерительного блока. - Сетевой электронный научный журнал "Системотехника", 2012, № 10.

Golyaev Y. D., Kolbas Y. Y., Konovalov S. F., Tomilin A. V. Criteria for choosing accelerometers for an inertial measuring unit.Network electronic scientific journal "System Engineering", 2012, № 10 .

4. Голяев Ю.Д. С курса не собьемся. - Ведомости "Русского оптического общества", 2015, № 1, с. 36-39.

Golyayev Y. D. Don't lose your direction. - Bulletin "Russian Optical Society", 2015, No. 1, p. 36-39

5. Голяев Ю.Д., Житенев О.С., Иванов М.А., Колбас Ю. Ю., Крутиков А. П., Соловьева Т. И. Алгоритм работы и программное обеспечение инерциального измерительного блока на зеемановских лазерных гироскопах и кварцевых акселерометрах. Качество. Инновации. Образование, 2015, № 10 (125), с. 39-53. Golyaev Y. D. , Zhitenev O. S., Ivanov M. A., Kolbas Y. Y., Krutikov A. P., Solovyova T. I. Algorithm of operation and software of the inertial measuring unit on Zeeman laser gyroscopes and quartz accelerometers. - Quality. Innovation. Education, 2015, No. 10 (125), p. 39-53 the accuracy of the experiment, which is apparently the limiting effect on the strength of the construction of gyroscopes and accelerometers.

\section{CONCLUSION}

The investigations conducted have shown that changes in the orientation matrix of accelerometers at temperature, impact, vibration effects are determined by $90 \%$ by the accelerometer itself. In this regard, the installation of gyroscopes and accelerometers on the same mounting planes of the IMU is not mandatory. This significantly improves the maintainability of the IMU and reduces the overheating of the accelerometers. The use of thermal correction of the orientation matrix by a linear function makes it possible to reduce the error to the errors of the accelerometers. The proposed IMU design with the separate arrangement of gyroscopes and accelerometers also provides mechanical strength by the criterion of maintaining the orientation of the measuring axes of inertial sensors to high levels of mechanical effects. 